\title{
FACTORS AFFECTING THE LEVEL AND STRUCTURE OF INSTITUTIONAL CONSUMPTION ON THE CRUISE SHIPPING MARKET
}

JOANNA KIZIELEWICZ

Gdynia Maritime University, POLAND

e-mail: j.kizielewicz@wpit.am.gdynia.pl

\section{RECEIVED}

ACCEPTED

JEL

CLASSIFICATION

KEYWORDS

ABSTRACT
12 April 2018

2 September 2018

M20, 012

institutional consumption, cruise tourism, cruise ships

It follows from the data of Cruise Market Watch (2016) that nowadays there are in total 52 cruise lines managing the fleet of 298 cruise ships on the cruise shipping market. Cruise ship companies aspire to increase the sales volume on a regular basis in order to generate profits, but strong competition on the market forces them into saving and minimizing cruise travel unit costs per one passenger. These activities aim at reducing cruise travel prices to attract more and more travellers. Therefore, cruise travel operators strive to find various solutions, including e.g. those related to modelling the cooperation with goods suppliers and service providers or seek other solutions. The objective of this study is to identify factors affecting the cooperation between cruise ship companies and goods and services producers and providers. The research results can constitute interesting plausible material for entities involved in rendering services on the market of cruise ship tourism in coastal tourist destinations.

\section{Introduction}

According to M. Gorynia (1999, p. 779) "new institutional economics represents interdisciplinary approach to economic phenomena" including the theories of economics, theories of organization and jurisprudence. M. Gorynia (1999, p. 778) believes that „company is a network of contracts the essence of which being the form of employment (...), and the company objective involves profit maximization". Whereas, M.E. Sokowicz (2015, p. 197) believes 
that "institutions within the new institutional economics are perceived (...) as a set of limitations for the operation of entities striving to maximize their own usability". On the other hand, institutional consumption refers to the relations between entities representing the economic and/or public sectors which aim at producing and supplying goods and services to individual consumers. A. Szwajlik (2015, p. 43.) emphasizes that institutional consumption occurs when the clients of service companies include legal persons, the so-called institutional purchasers (entrepreneurs). Each sector of economy is characterized by another group of entities which establish mutual business relations to produce and supply the final product or service to individual consumer (the so-called final consumer). In the case of cruise shipping market individual consumers include cruise ship travellers, whereas institutional consumers include a wide range of entities involved in preparing, promoting and supplying the cruise ship offer. This phenomenon has only been ambiguously defined in reference publications, in particular when it comes to the sector of maritime economy and tourist industry.

According to Florida Caribbean Cruise Association (FCCA, 2017, pp. 3-4), in 2016 another record was broken as for the number of cruise ship travellers amounting to as many as 24.2 million of travellers, which constituted an increase by 4 per cent compared to 2015 with 23.2 million of travellers. The increase in demand for cruise travels among various groups of travellers exerts influence on the activities taken by cruise ship companies. They decide to purchase new cruise ships, which involves incurring long-term financial liabilities to various financial institutions. The newly built ships are increasingly larger and more expensive, such as e.g. Harmony ship built at STX France shipyard for the Royal Caribbean Cruise Lines regarded as the most expensive (1.3 billion dollars) and at present the largest cruise ship (225 $282 \mathrm{GT}$ ) introduced into the market. The ship can take on board over 6 thousand passengers plus crew (Royal Caribbean Cruises Ltd., 2014, p. 96). The maintenance and services of large ships require from cruise ship companies engaging more goods suppliers and service providers to ensure good quality and variety of goods and services offered on the ship. Whereas, the increase in the number of passengers results in growing needs related to passenger service at departure ports (the so-called home ports) and visited ports (the socalled ports of call). Cruise ship companies have to establish business relations with numerous economic entities in the ports of call, i.e. with local carriers, tour guides and tour operators to render services for thousands of travellers. Strong competition on the market forces cruise ship companies to minimize transactional costs to reduce unit costs per cruise ship passenger so they can provide potential customers with more favourable cruise travel offer.

The objective of this study is to identify factors affecting the cooperation between cruise ship companies and goods and services producers and providers. In this study the following research questions were formulated: (1) What kind of entities participate in institutional consumption on the market of cruise ship tourism? (2) What is the level and structure of institutional consumption represented by the leading cruise ship companies? In this study, exploratory method was applied as well as deductive approach and "desk research" method. The analysis of existing materials was conducted, including the reports of world known organizations studying the cruising market, and scientific papers from trade publications and also annual reports and marketing strategies of the leading cruise ship companies.

\section{Entities on the cruise ship tourism market}

The entities operating on the cruise shipping market can be analysed from the supply and demand point of view. The first group includes mainly cruise ship operators who are at the same time cruise ship owners, ship building companies and global tour operators and tourist agencies offering cruise travels, but also travel agent's at 
the visited coastal tourist destinations (ports of call) responsible for providing attractive sightseeing offers (the socalled shorex - excursion on the shore). Apart from the a/m entities, on the cruise shipping market there are also numerous entities handling and supplying shops in home port, i.e. sea ports management, maritime agencies, port companies, producers and suppliers of food produce, hygiene and sanitary produce and cosmetics, and also clothing and other products (to on-board stores), and the suppliers of petroleum and water and other products indispensable for the ship to operate and handle thousands of passengers and crew members (Figure 1).

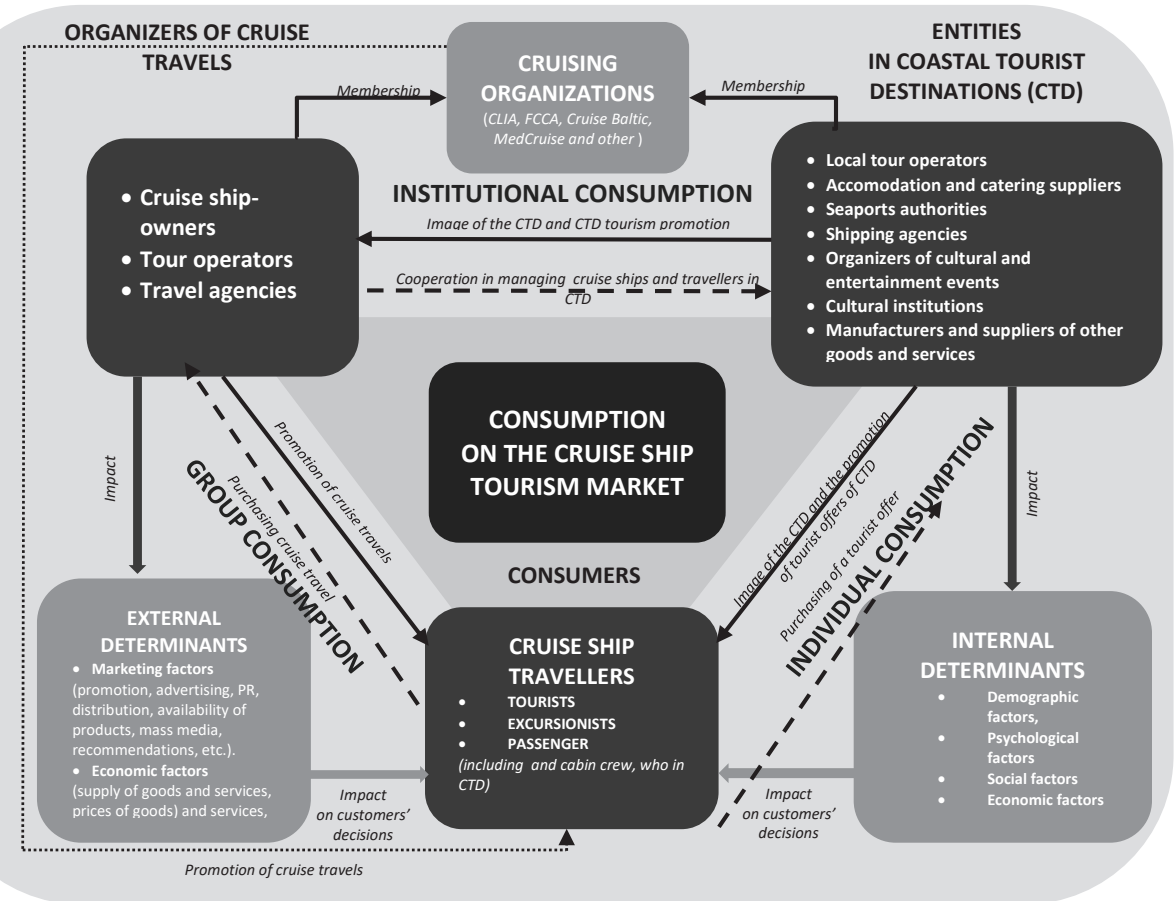

Figure 1. The model for the development of cruise travellers' consumption in coastal tourist destinations

Source: own elaboration (Kizielewicz, 2016, p. 281).

Whereas, entities operating on the demand side of cruise shipping market are represented by passengers who, depending on time they spend in visited destinations and volume and structure of consumption, can perform various functions relative to the visited tourist destinations, i.e. the function of excursionists ( $<24 \mathrm{~h}$ ) or tourists ( $>24 \mathrm{~h}$ ), and also passengers who do not take the offer presented at coastal destinations (Kizielewicz, 2016, p. 93). Among the entities operating on the cruise shipping market there are thousands of crew members and on-board personnel who, on the one hand, render services for ship owners and passengers, and on the other, represent the demand for work.

The increasing demand for cruise ship travels results from the fact that cruise ship-owners, for one thing, enlarge their cruise ship fleet, and for another, seek to attract clients on a very competitive market. It requires 
cooperation with numerous entities and continuous work to establish good relations in order to ensure good quality of offered services for reasonable (meaning: competitive) prices acceptable for the majority of passengers.

The subject of analysis in this study refers to institutional consumption, namely business relations between entities on the supply side of cruise shipping market. The leading entities on this market include cruise ship owners who choose contractors to cooperate with in home ports, ports of call and also incoming ports. The role of coastal tourist destination on the market of cruise ship tourism determines the volume and scope of business relations between cruise ship owners and goods suppliers and service providers.

\section{Factors affecting the volume and structure of institutional consumption}

Cruise ship owners select tourist destination where they intend to run business activities generating, as a result, the demand for various goods and services in order to handle their fleet of ships and passengers. They seek partners for cooperation by negotiating favourable market conditions. Business relations between the $\mathrm{a} / \mathrm{m}$ entities constitute typical examples of institutional consumption. The volume and structure of institutional consumption on the cruise shipping market are influenced by numerous factors, among them the most important include, e.g.:

- formal and legal requirements (MARPOL, SOLAS conventions and other),

- function of sea port on the cruise shipping market (home port, port of call, incoming port),

- state of infrastructure and development level of service facilities in cruise sea ports and in their vicinity,

- management strategy in cruise ship companies,

- scope of activity and type of offer presented by cruise ship owners,

- competition on the cruise shipping market resulting from introducing new and larger cruise ships onto the market,

- seeking savings by cruise ship owners in order to reduce unit costs (price competition),

- changes in global demand manifested by the increase in the number of passengers representing various age groups of other preferences relative to the type leisure activities (mass tourism).

Cruise ship companies are obliged to respect various regulations concerning safety at sea and protection of marine environment. It is stated e.g. in MARPOL convention (International Convention for the Prevention of Pollution from Ships) (MARPOL, 1972). In cruise sea ports sewage and waste water are collected for a fee, which requires contracts between ship owners and receivers, namely port authorities or port companies and sometimes local authorities who own the sewage collection facilities and systems.

The largest volume of business transactions between entities on the supply side of the cruise shipping market refers to regions where home ports are located, where the ships begin and end their cruise travels. They are usually the seats of cruise ship owners and location of facilities for handling cruise ships (passenger quays, facilities for supplying ships with petroleum and water, sewage collection, port companies handling pilotage, towing and mooring of ships, etc.) and passengers (passenger terminals with all the facilities, car park for vehicles and buses on land, car rental services, etc.). Smaller number of business transactions related to handling cruise ships can be observed between ship owners and other entities in the ports of call and incoming ports. They are limited mainly to indispensable operations related to handling ships in the port. Most frequently they refer to towing, pilotage and mooring the ship, protection of ship in the port and supply of petroleum and water for further travel, which is provided by port companies operating within the port. The new EU regulations require sea port authorities to adjust the ports 
to collect waste water from passenger ships; otherwise in a few years they will not be able to handle such ships. These and other restrictions require, so to speak, establishing trade contracts between cruise ship owners and service providers in the ports of call.

Significant impact on the volume of transactions concluded between cruise ship owners and market entities comes from preparing the facilities available in sea ports. Sometimes, ship owners are forced to establish business relations with entities located outside port areas, which is caused by poor port infrastructure and unavailability of particular services in the port, and then external companies supply water or petroleum to the ship with the use of water carts.

The key factor on the volume of business transactions comes from the cruise ship company development strategy. In the day of strong competition on the market, including tourist market, cruise ship owners reach for various management strategies. The conducted studies (Kizielewicz, 2017, p. 314) prove that leading cruise ship companies reach for various strategies, such as e.g. CCL - applies cost and demand strategy, RCCL - coast and demand strategy and market penetration, and $\mathrm{NCL}$ - demand and competition strategy. Today, cruise travels are recognized as part of the strongly developing sector of mass tourism. Therefore, cruise ship companies face challenges related to preparing the leisure time offers for a wide group of travellers of different interests and personality profiles. It requires establishing cooperation with various entities based on business contracts - institutional consumption. Within the savings strategies, cruise ship owners decide not to order services from external companies but from newly established daughter companies handling ships and passengers. Such strategy is applied e.g. by Norwegian Cruise Line who purchased a private island where they transport passengers, and provide their own hotels, restaurants and tourist agencies offering tourist services.

Many cruise travels aim at visiting attractive and popular coastal tourist destinations. Therefore, cruise ship companies provide two solutions, i.e. they cooperate with local tour operators ordering attractive tourist programs and passenger service from them or establish their own travel agent's responsible for passenger service on land. For instance, Carnival Corporation \& plc managing Westours and Princess Tours in Alaska own a fleet of 500 coaches and 20 railway carriages (Klein, 2006, p. 264).

\section{Volume and structure of institutional consumption on the eruise shipping market}

The studies conducted by Business Research \& Economic Advisors (BREA) regarding the economic impact of the cruise shipping market on coastal tourist destinations prove that between 2014 and 2015 the total income amounted to 3.16 billon American dollars and it was recorded in only 35 most important coastal tourist destinations which participated in the study (BREA, 2015). Institutional consumption, and in particular expenses incurred by cruise lines relative to calling at seaports, including harbour charges and taxes, and charges for services provided by local tour operators and other suppliers of goods and services was estimated at 400.8 million American dollars. It was also estimated that average costs incurred by cruise ship owners for one call of 130,000 GRT cruise ship with 3,000 passengers on board and 1,250 crew members totalled 110,000 American dollars (FCCA, 2017, p. 4).

CLIA provides that in 2016 cruise ship owners cooperated with 25 thousand travel agents involved in promoting and distributing their tourist offer around the world (Kennedy, 2017, p. 16). 
Table 1. Cruise ship-owners expenses in 2016 in billion USD

\begin{tabular}{lcccrr}
\hline \multicolumn{1}{c}{ Expenses } & USA & $\begin{array}{c}\text { Rest of the } \\
\text { North America }\end{array}$ & Europe & $\begin{array}{r}\text { Rest of the } \\
\text { World }\end{array}$ & Total \\
\hline Expenses of cruise ship owners $(\$)$ & 17.20 & 1.25 & 15.22 & 4.99 & 38.66 \\
Share (\%) & 44.49 & 3.23 & 39.37 & 12.91 & 100.00 \\
\hline
\end{tabular}

Source: CLIA (2016), p. 20.

Cruise line owners notify of their demand for various goods and services. It requires establishing cooperation with numerous producers and suppliers of goods and services in home ports and ports of call. According to CLIA calculations, in 2016 ship owners spent worldwide on consumption goods for cruise ships, taxes and harbour charges, commission for tourist agents and administrative expenses and remuneration for employees on land and ship crew the total amount of over 36.66 billion American dollars (CLIA, 2016, p. 20). More than 17.2 billion American dollars, which constituted $44 \%$ of global market share, referred to expenses incurred by cruise ship owners for institutional consumption in the United States, where seats of the three most important cruise ship companies are located, i.e. Carnival Cruise Line, Royal Caribbean International and Norwegian Cruise Line. Moreover, in the US there are the most important home ports handling the largest number of cruise ships, i.e.: Miami, Tampa and Everglades on Florida and San Francisco, Los Angeles and San Diego on the West Coast of the United States. Whereas, in Europe in 2016, cruise line owners spent on institutional consumption in total 15.22 billion American dollars, which constitutes $39.37 \%$ share on the global market. It is worth emphasizing that the dominant role was played by three main home sea ports, i.e. in Barcelona, Copenhagen and Southampton (Table 1).

The highest costs on the part of cruise ship owners refer to orders for new cruise ships at shipyards. Here, we can observe the necessity to establish cooperation between cruise ship owners and financial institutions in order to obtain capital for the purchase and maintenance of newly built ships. Therefore, cruise ship companies cooperate with various entities, i.e. banks, leasing companies, investment funds and private investors. Additionally, cruise ship owners need to take care of the technical state of their fleet, which requires cooperation with entities rendering services regarding maintenance, repairs and modernization of cruise ships. According to Cruise Ship Orderbook until 2020 (CLIA, 2015, p. 2) cruise ship owners contracted the purchase of new cruise ships in the amount of over 24.8 billion dollars.

In order to meet market trends cruise ship companies provide travellers with tourist packages containing not only cruise travel but also flights to home ports, transport from airports to hotels, and accommodation before and after cruise travel (flight \& cruise package). Preparing such offers requires cooperation with airlines, local transport carriers in home ports and hotel chains. We can also observe here the phenomenon of institutional consumption since cruise ship owners establish business relations with the $\mathrm{a} / \mathrm{m}$ entities to ensure services for their passengers.

The studies by CLIA Europe proved that in 2015 cruise ship companies in Europe spent 16.89 billion euro (Table 2), including significant amount, i.e. 4.6 billion euro of liabilities towards shipyards related to the purchase of new cruise ships as well as renovation and maintenance of cruise ship fleet, and 1.44 billion euro - liabilities towards companies for financial, insurance, advertising services and other. Moreover, cruise ship owners had to pay as much as 815 million euro to tourist agents for the distribution and sale of cruise ship offers and 590 million euro was spent to cover liabilities resulting from petroleum supply on ships. In 2015, in Europe expenses for cruise ship supply with food and beverages amounted to 690 million euro in total. In the cruise ship owner's budget significant 
expenses referred to the organization of passenger service, namely the cost of flight purchased as flight \& cruise packages and their stay at home ports (accommodation and food), and flight after the cruise, and also tourist services at the ports of call. Expenditure resulting from cooperation with subcontractors in the ports amounted to 3.83 billion euro in total (CLIA Europe, 2016, p. 4).

Table 2. Direct cruise lines purchases by industry (millions), 2015 (excluding shipbuilding)

\begin{tabular}{lcc}
\hline \multicolumn{1}{c}{ Industry } & $\begin{array}{c}\text { Purchases } \\
€ \text { Million }\end{array}$ & $\begin{array}{c}\text { Shares in Total } \\
(\%)\end{array}$ \\
\hline Agriculture, Mining and Construction industries & 20 & 0.3 \\
Food \& Beverage & 687 & 10.0 \\
Textiles \& Apparel & 195 & 2.8 \\
Paper \& Printing & 185 & 2.7 \\
Petroleum \& Chemicals & 789 & 11.4 \\
Stone \& Glass & 28 & 0.4 \\
Metals & 223 & 3.2 \\
Machinery & 766 & 11.1 \\
Other Manufacturing & 410 & 5.9 \\
Wholesale Trade & 112 & 1.6 \\
Transportation \&Utilities & 1,668 & 24.2 \\
Financial \& Bus. Services & 1,427 & 20.5 \\
Personal Service. \& Government & 400 & 5.8 \\
\hline Total & 6,900 & 100.0 \\
\hline
\end{tabular}

Source: CLIA Europe (2016), p. 17.

More thorough analysis of expenditure incurred by cruise line owners in Europe in 2015 proved that the most substantial expenses in the budget, i.e. as much as $20.5 \%$ refer to financial \& bus services and the purchase of petroleum \& chemicals (11.4\%), and also purchase of various devices (11.1\%) and food \& beverage (10.0\%) (Table 2). The producers of food and beverages delivered on the ships recorded income of 687 million euro. Moreover, the petrochemical industry recorded income of 789 million euro resulting from the supply of petroleum on cruise ships. Cruise ship owners also purchased various equipment and machines, such as e.g.: engines, lighting and communication equipment and computers for 989 million euro. The call of cruise ships in ports involves paying harbour charges and incurring costs of services rendered within the port for the cruise ship owner. The $\mathrm{a} / \mathrm{m}$ expenses on the part of cruise ship owners amounted to 1.6 million euro (CLIA Europe, 2016, p. 17).

Table 3. Cruise industry expenditures for new buildings and refurbishment (millions), 2015

\begin{tabular}{lccc}
\hline \multicolumn{1}{c}{ Country } & New buildings $€$ Million & Refurbishment $€$ Million & Total $€$ Million \\
\hline Germany & 961 & 316 & 1,277 \\
Italy & 1,006 & 261 & 1,267 \\
France & 470 & 53 & 523 \\
Finland & 432 & 73 & 505 \\
Other EU + 3 & 803 & 229 & 1,032 \\
\hline Total & 3,672 & 932 & 4,604 \\
\hline
\end{tabular}

Source: CLIA Europe (2016), p. 17. 
In Europe until 2019, numerous investments have been planned regarding the construction of new fleet of cruise ships and renovation of the existing one. The largest investments regarding the construction of new ships between 2016 and 2019 have been planned in Italy with resources amounting to more than 1 billion euro, and in Germany - 961 million euro. In these countries the majority of expenses were taken by repairs and renovations of the existing cruise ships. In Germany, significant part of investment is scheduled for another AIDA Cruises ships. Furthermore, in Germany and Italy thriving shipyards building cruise ships are located, which significantly improves the development of investments.

\section{Conclusions}

Summing up, it is worth emphasizing that cruise ship companies are forced to cooperate with various economic and public entities on the market in order to handle the fleet of ships and passengers in home ports and ports of call. Since every year the number of cruise ship travellers has been increasing, which results in ordering larger and larger cruise ships, cruise ship owners have to establish various forms of cooperation with subcontractors and different contractors. Taking care of competitive offers on the market, cruise ship companies minimize the costs of business operations by providing at the same time proper quality of service (value for money) and consequently apply various strategies, such as e.g.:

1. Concluding long-term business contracts with contractors to negotiate more favourable terms of transactions, in particular in home ports.

2. Preparing package offers to reduce costs of travel for consumers and improve their comfort, which requires cooperation with carriers and companies from the tourist and hotel sector.

3. Establishing own travel agent's in coastal tourist destinations to reduce costs of passenger service on land (the so-called shorex).

4. Investing in the purchase of private islands on the Caribbean Sea, and in hotel and catering infrastructure to reduce the number of external orders in the ports of call.

5. Minimizing unit costs per one cruise ship passenger by establishing active price policy in cruise ship companies.

6. The demand for consumer goods and services generated by cruise ship companies provides an incentive to establish new production companies and service providers in the vicinity of ports visited by cruise ships. As a result, new workplaces are created, tourist and para-tourist infrastructure is developed, and all of this exerts positive influence on the social and economic development of coastal tourist destinations.

\section{References}

BREA (2015). Economic Contribution of Cruise Tourism to the Destination Economies. Business Research \& Economic Advisors.

CLIA (2015). Cruise Ship New Order Schedule Q1 2015. Miami, Florida: Cruise Line International Association.

CLIA (2016). The Global Economic Contribution of Cruise Tourism 2015. Business Research \& Economic Advisors, CLIA, Exton.

CLIA Europe (2016). Contribution of Cruise Tourism to the Economies of Europe 2015. Miami: CLIA.

Cruise Market Watch (2016). Retrieved from: http://www.cruisemarketwatch.com/market (20.10.2017).

FCCA (2017). Cruise industry overview 2017, State of the Cruise Industry. Miami, Florida: Caribbean Cruise Association.

Gorynia, M. (1999). Przedsiębiorstwo w nowej ekonomii instytucjonalnej. Ekonomista, 6 (69), Miscellanea, 778-779.

Kennedy, S. (2017). Crusie Line Outlook, December 2016. Miami: Cruise line International Association Inc. 
Kizielewicz, J. (2017). Kształtowanie cen ofert tuystycznych na rynku usług morksiej żeglugi wycieczkowej. Prace Naukowe Uniwersytetu Ekonomicznego we Wrocławiu, 473.

Kizielewicz, J. (2016). Konsumpcja podróżujących morksimi statkami wycieczkowymi w nadmorksich obszarach recepcji truystycznej. Gdynia: Wydawnictwo Akademii Morskiej w Gdyni.

Klein, R.A. (2006). Turning Water into Money: The Economics of the Cruise Industry. In: K. Dowling (ed.), Cruise Ship Tourism. CAB International.

MARPOL (1972). Międzynarodowa Konwencja o zapobieganiu zanieczyszczenia morza przez statki. 2.11.1973 r. (Dz.U. 5.06.1987).

Royal Caribbean Cruises Ltd. (2014). Annual Report. Miami: Royal Caribbean Cruises Ltd.

Sokowicz, M.E. (2015). Rozwój terytorialny w świetle teorii ekonomii instytucjonalnej. Przestrzeń - biskość - instytucje. Łódź: Wydawnictwo Uniwersytetu Łodzkiego.

Szwajlik, A. (2015). Konsument jako podmiot na rynku. In: G. Rosa (ed.), Konsument na rynku usług. Warszawa: C.H. Beck.

Cite this anticle aS: Kizielewicz, J. (2018). Factors affecting the level and structure of institutional consumption on the cruise shipping market. European Journal of Service Management, 3 (27/1), 109-117. DOI: 10.18276/ejsm.2018.27/1-13. 